\title{
Histoplasmin and Tuberculin Sensitivity
}

-Florida, 1954-

\author{
BY JAMES O. BOND, M.D., and ERMA WHITLOCK, R.N.
}

$\mathrm{I}^{\mathrm{N}}$ $\mathrm{N}$ the rapidly accumulating literature on the epidemiology of histoplasmosis, varying reports are given on the incidence of positive skin test reactors to histoplasmin in Florida. Christie and Peterson (1) tested 30 Florida residents in a survey of admissions to Vanderbilt Hospital and found 20 percent positive. Palmer (2) reported 4.3 percent positive in a group of 70 nurses tested in Florida during the course of a nationwide survey. Loosli and others (3) in their survey of University of Chicago students tested 109 from Florida and found 12.8 percent positive.

Since histoplasmosis was originally described as a tropical disease (4), it was felt that it would be of interest to obtain more accurate statistics on the incidence of exposure in Florida, which is perhaps the most nearly tropical State and serves as a portal of entry for

Dr. Bond, health officer for Hardee, De Soto, and Charlotte Counties, Florida, is currently on leave of absence to study at the Johns Hopkins University. Miss Whitlock is the public health nurse for De Soto County.

Everett Williams, director of the bureau of vital statistics, and Dr. D.S. Doff of the bureau of tuberculosis control, Florida State Board of Health; and Dr. Frank E. Daves and staff of the Arcadia Branch of the Florida State Hospital assisted in the preparation of this report. many visitors and emigrants from the tropical countries of the Western Hemisphere.

\section{Methods}

The group included in the present study consisted of 845 white patients in the Arcadia branch of the Florida State Hospital for the mentally ill. This is not an adequate sample from which accurate conclusions may be drawn regarding the general population of the State; however, it is offered as the best sample available to date. No disturbed patients or patients in the infirmary were subjected to the tests. An attempt was made to determine the length of residence of the subjects both in the State of Florida and in its respective counties. Individuals who have lived 50 percent or more of their lives in the State or a county were considered life-long residents. These criteria were arbitrary, there being no agreement among other investigators as to what constitutes lifelong residence (2-7).

Since the population of Florida largely consists of migrants from other States, it was felt that less rigid criteria for permanent residence were needed for this study. However, individuals who had at any time lived in the endemic States of Tennessee, Arkansas, Kentucky, Missouri, Indiana, Illinois, Ohio, Kansas, Mississippi, or Louisiana were excluded insofar as statistics for Florida residents were concerned.

The testing procedure consisted of the intra- 
dermal injection of 0.1 cc. of a $1: 100$ dilution of histoplasmin concentrate (A) on the volar surface of the arm. Simultaneously, the opposite arm was injected with a 0.1-cc. solution containing $.0001 \mathrm{mg}$. of purified tuberculoprotein derivative (B) as prepared by the method of Seibert and Glenn. New syringes and platinum needles appropriately labeled and restricted to each antigen were used throughout. These tests were read in 72 hours and were defined as positive if there was an area of induration $5 \mathrm{~mm}$. in diameter or more. All other reactions were called negative in this series. All tests were performed and read by the same two individuals. Analyses of the results for statistical significance were based on a 95-percent probability.

\section{Results}

The overall results are given in table 1 . It can be seen that 11.7 percent of the total group reacted positively to histoplasmin. This is roughly the same as the 12.8 percent obtained by Loosli and associates (3), but it is higher than the 4.3 percent obtained by Palmer (\&) and would place Florida in his region VI rather than region IX. However, this would not change Florida's position as on the periphery of the area of endemic histoplasmosis in the United States.

Of the 476 life-long residents of Florida in the total group, 8.0 percent were histoplasmin positive, whereas 16.5 percent of the nonresidents were positive. This is a statistically significant difference.

Of the total group, 54.4 percent reacted positively to intermediate strength tuberculin. The difference between the rates for Florida resi- dents (52.9 percent) and that of the nonresidents (56.3 percent) is not significant. The incidence of tuberculosis infection in mental hospital patients is higher than that in the general population and would be expected to reflect in higher tuberculin positive rates. It will be the purpose of the authors to establish later the tuberculin positive conversion rates for this group and compare these rates with those in the general population and with other mental hospital groups.

Function of sex. Of the total male group 13.7 percent were histoplasmin positive compared with 9.6 percent of the females. In the life-long residents of Florida, these figures were: males, 10.6 percent and females, 5.1 percent (table 2). These differences are not statistically significant. Other investigators have found a similar slight sex difference with males usually higher. In the case of the tuberculin test, the percentage of reactors among males was also higher than among females. However, this difference was not statistically significant for the life-long residents.

Function of age. The highest percentage of positive histoplasmin reactors was found in the 30 - to 40-age group of life-long Florida residents. This is similar to the findings in other States $(1,3,4)$ where the incidence rose very rapidly in the preadolescent and adolescent groups then leveled out, reaching a gradual peak in the fourth decade. The lowest percentage in this study (2.6 percent) was in the 20 - to 30-age group. Most reactors to tuberculin were found in the 50- to 60-age group, which corresponds with the results of other surveys.

Function of geography. Of the residents of northern Florida counties 8.5 percent developed a positive skin test to histoplasmin compared

Table 1. Reactors to histoplasmin and tuberculin skin test antigen, Florida State Hospital, Arcadia, Fla., 1954

\begin{tabular}{|c|c|c|c|c|c|c|c|c|c|c|}
\hline \multirow[b]{2}{*}{ Item } & \multirow[b]{2}{*}{ Total } & \multicolumn{2}{|c|}{ Sex } & \multicolumn{5}{|c|}{ Age group } & \multicolumn{2}{|c|}{ Residence } \\
\hline & & Male & $\underset{\text { male }}{\mathrm{Fe}}$ & 20-29 & $30-39$ & $40-49$ & $50-59$ & $\begin{array}{c}60 \text { and } \\
\text { over }\end{array}$ & Florida & $\begin{array}{c}\text { Non- } \\
\text { Florida }\end{array}$ \\
\hline $\begin{array}{l}\text { Number tested. } \\
\text { Histoplasmin reactors (percent) } \\
\text { Tuberculin reactors (percent) }\end{array}$ & $\begin{array}{r}845 \\
11.7 \\
54.4\end{array}$ & $\begin{array}{r}430 \\
13.7 \\
60.9\end{array}$ & $\begin{array}{r}415 \\
9.6 \\
47.7\end{array}$ & $\begin{array}{r}54 \\
9.2 \\
40.7\end{array}$ & $\begin{array}{r}166 \\
13.2 \\
53.0\end{array}$ & $\begin{array}{r}229 \\
10.0 \\
51.9\end{array}$ & $\begin{array}{r}216 \\
13.8 \\
59.2\end{array}$ & $\begin{array}{r}180 \\
10.5 \\
54.4\end{array}$ & $\begin{array}{r}476 \\
8.0 \\
52.9\end{array}$ & $\begin{array}{r}369 \\
16.5 \\
56.3\end{array}$ \\
\hline
\end{tabular}


Table 2. Histoplasmin and tuberculin rates for life-long Florida residents, 1954

\begin{tabular}{|c|c|c|c|c|c|c|c|c|c|c|c|}
\hline \multirow{2}{*}{ Item } & \multirow{2}{*}{ Total } & \multicolumn{2}{|c|}{ Sex } & \multicolumn{5}{|c|}{ Age group } & \multicolumn{3}{|c|}{ Residence } \\
\hline & & Male & $\underset{\text { male }}{\mathrm{Fe}-}$ & $20-29$ & $30-39$ & $40-49$ & $50-59$ & $\begin{array}{c}60 \text { and } \\
\text { over }\end{array}$ & Northern & Central & Southern \\
\hline $\begin{array}{l}\text { Number tested } \\
\text { Histoplasmin reactors } \\
\text { (percent) } \\
\text { Tuberculin react ors } \\
\text { (percent) }\end{array}$ & $\begin{array}{r}476 \\
8.0 \\
52.9\end{array}$ & $\begin{array}{r}245 \\
10.6 \\
56.3\end{array}$ & $\begin{array}{r}231 \\
5.1 \\
49.3\end{array}$ & $\begin{array}{r}39 \\
2.6 \\
43.5\end{array}$ & $\begin{array}{r}115 \\
11.3 \\
45.2\end{array}$ & $\begin{array}{r}140 \\
5.0 \\
55.7\end{array}$ & $\begin{array}{r}108 \\
9.2 \\
58.3\end{array}$ & $\begin{array}{r}74 \\
9.4 \\
50.0\end{array}$ & $\begin{array}{r}82 \\
8.5\end{array}$ & $\begin{array}{l}302 \\
6.9\end{array}$ & $\begin{array}{r}92 \\
10.8\end{array}$ \\
\hline
\end{tabular}

with 6.9 percent in central Florida and 10.8 percent in southern Florida. These differences are not statistically significant. Of 150 lifelong residents of the Tampa Bay area 6.0 percent were positive compared with 68 residents of the Miami-Key West area of whom 13.2 percent reacted positively. Of the non-Florida residents 16.5 percent had a positive histoplasmin skin test, and 47.1 percent of these positive reactors came from endemic States of the Mississippi Valley basin.

Correlation with pulmonary calcification. A total of 711 of the 845 patients receiving skin tests had received 70-mm. X-rays the year previously during a mass survey. These were reviewed especially for evidence of pulmonary calcification by Dr. S. D. Doff of the Florida State Board of Health. The results as correlated with the skin tests are given in table 3. Of the single histoplasmin reactors 13.8 percent had pulmonary calcifications on $\mathbf{X}$-ray compared with 4.8 percent of the single tuberculin reactors. This twofold difference, although of doubtful significance in this study, is similar to previous findings which have established the positive correlation found between pulmonary calcifications and positive histoplasmin tests.

\section{Discussion}

The results of this study conform to the results of previous investigations that place Florida on the periphery of the area of endemic asymptomatic histoplasmosis infection in the United States. We feel that this also lends weight to the theory that the disease is not spread by human contact. If the disease were so spread it would have been ex- pected that Florida would have a higher incidence than a peripheral State since Florida has many migrants both from the tropics where rates of exposure are relatively high $(8)$ and from the endemic areas in the United States.

That there was no significant change in the rates of positive histoplasmin reactors in northern, central, and southern Florida was of some interest. Since south Florida is from 300 to 500 miles farther distant from the Mississippi Valley basin than northwest Florida it might be expected to have a lower rate, but our evidence shows there is no significant decrease of the rate in south Florida. It should be remembered, of course, that the evidence we have presented is insufficient to definitely establish this as a fact.

The significant difference between the histoplasmin rates for life-long Florida residents (8.0 percent) and nonresidents (16.5 percent) is thought to be due to the fact that approximately $\mathbf{5 0}$ percent of these nonresidents came

Table 3. Hisfoplasmin and fuberculin reactors with pulmonary calcifications, Florida State Hospital, Arcadia, Fla., 1953

\begin{tabular}{|c|c|c|c|c|c|}
\hline \multirow[b]{2}{*}{ Item } & \multirow[b]{2}{*}{ To- } & \multicolumn{3}{|c|}{ Reactors } & \multirow[b]{2}{*}{$\begin{array}{l}\text { Non- } \\
\text { reac- } \\
\text { tors }\end{array}$} \\
\hline & & $\begin{array}{l}\text { Histo- } \\
\text { plas- } \\
\text { min }\end{array}$ & $\begin{array}{c}\text { Tuber- } \\
\text { culin }\end{array}$ & $\begin{array}{l}\text { Histo- } \\
\text { plas- } \\
\text { min } \\
\text { and tu- } \\
\text { bercu- } \\
\text { lin }\end{array}$ & \\
\hline $\begin{array}{c}\text { Number tested. } \\
\text { Calcification on } \\
\text { X-ray: } \\
\text { Number. } \\
\text { Percent... }\end{array}$ & $\begin{array}{r}711 \\
29 \\
4.0\end{array}$ & $\begin{array}{r}4 \\
13 . \\
8\end{array}$ & $\begin{array}{r}15 \\
4.8\end{array}$ & 6. $\begin{array}{r}2 \\
0\end{array}$ & 2. $\begin{array}{r}8 \\
06\end{array}$ \\
\hline
\end{tabular}


from States having a high rate of histoplasmin positive reactors.

\section{Summary and Conclusions}

Eight hundred forty-five whits patients in a hospital for the mentally ill in central Florida were given histoplasmin and tuberculin skin tests. Of the number 11.7 percent were histoplasmin positive and 54.4 percent were tuberculin positive. Of the 476 life-long residents of Florida in this group, 8.0 percent were histoplasmin positive and 52.9 percent, tuberculin positive.

These residents of Florida are thus shown to be on the periphery of the area of endemic histoplasmosis in the United States. There was no significant difference in the histoplasmin positive rates found for groups of individuals who had lived in either northern, central, or southern Florida 50 percent of their lives.

Movement of individuals from the areas of endemic histoplasmosis into Florida and the varying distances of residents in northern and southern Florida from the Mississippi Valley basin have not influenced the histoplasmin positive rates.

\section{EQUIPMENT REFERENCES}

(A) Histoplasmin concentrate (lot CT-189), Eli Lilly and Company, Indianapolis, Ind.
(B) PPD tuberculin tablets, intermediate strength, Sharpe \& Dohme, West Point, $\mathbf{P a}$.

\section{REFERENCES}

(1) Christie, A., and Peterson, J. C.: Histoplasmin sensitivity. J. Pediat. 29: 417-432 (1946).

(2) Palmer, C. E.: Geographic differences in sensitivity to histoplasmin among student nurses. Pub. Health Rep. 61 : 475-487 (1946).

(3) Loosli, C. G., Baedenkopf, W. G., Rice, F. A., and Savage, L. G. : Epidemiological aspects of histoplasmin, tuberculin, and coccidioidin sensitivity. Am. J. Hyg. 53 : 33-57 (1951).

(4) Darling, S. T.: A protozoön Histoplasma capsulata general infection producing pseudotubercules in the lungs and focal necroses in the liver, spleen, and lymph nodes. J. A. M. A. 46: 1283-1285 (1906).

(5) Furcolow, M. L., High, R. H., and Allen, M. F.: Some epidemiological aspects of sensitivity to histoplasmin and tuberculin. Pub. Health Rep. 1132-1144 (1946).

(6) Prior, J. C., and Allen, M. F.: Geographic distribution of histoplasmin and tuberculin reactors among Ohio State University freshmen and student nurses training in Columbus, Ohio, hospitals. Pub. Health Rep. 62: 1608-1617 (1947).

(7) Furcolow, M. L., and Sitterley, J.: Further studies on the geography of histoplasmin sensitivity in Kansas and Missouri. J. Kansas M. Soc. 52 : 584-589 (1951).

(8) Mochi, A., and Edwards, P. Q.: Geographical distribution of histoplasmosis and histoplasmin sensitivity. Bull. World Health Org. 5 : 259-291 (1952).

\section{PHS Advisory Council Appointment}

\begin{abstract}
Dr. Eugene Anson Stead, Jr., has been appointed by the Surgeon General of the Public Health Service to serve on the National Advisory Arthritis and Metabolic Diseases Council. Dr. Stead will advise and make recommendations to the Surgeon General and to the director of the National Institute of Arthritis and Metabolic Diseases on the extramural activities of the institute. A professor of medicine at Duke University School of Medicine since 1947, Dr. Stead is also physician-in-chief of Duke Hospital, Durham, N. C. His prior associations during 1942-46 include serving as instructor and associate professor at Harvard Medical School, professor and dean, Emory School of Medicine, and physician-inchief, university division, Grady Hospital. Dr. Stead obtained his medical degree at Emory University.
\end{abstract}

